\title{
Implementation and Application of Artificial Intelligence in Selected Public Services
}

\author{
Nikola Štefanišinova* \\ Nikoleta Jakuš Muthova ${ }^{* *}$ \\ Jana Strangfeldováa* \\ Katarina Šulajovát***
}

\author{
https://doi.org/10.31297/hkju.21.4.2 \\ UDK: $\quad$ 351:004.3./.4 \\ 351:004.89 \\ Review scientific paper / pregledni znanstveni rad \\ Received / primljeno: 1. 2.2021. \\ Accepted / prihvaćeno: 10.12. 2021.
}

* Nikola Štefanišinová, PhD student, Faculty of Economics, Matej Bel University, Banská Bystrica, Slovakia (doktorska studentica Ekonomskog fakulteta Sveučilišta Matej Bel, Banská Bystrica, Slovačka, email: nikola.stefanisinova@gmail.com).

ORCID: https://orcid.org/0000-0001-7270-9498

** Nikoleta Jakuš Muthová, Assistant Professor, Faculty of Economics, Matej Bel University, Banská Bystrica, Slovakia, (docentica Ekonomskog fakulteta Sveučilišta Matej Bel, Banská Bystrica, Slovačka, email: nikoleta.jakusmuthova@umb.sk).

ORCID: https://orcid.org/0000-0001-8700-5055

*** Jana Štrangfeldová, Associate Professor, Faculty of Economics, Matej Bel University, Banská Bystrica, Slovakia, (izvanredna profesorica Ekonomskog fakulteta Sveučilišta Matej Bel, Banská Bystrica, Slovačka, email: jana.strangfeldova@umb.sk).

ORCID: https://orcid.org/0000-0003-1083-4909

**** Katarína Šulajová, PhD student, Faculty of Economics, Matej Bel University, Banská Bystrica, Slovakia (doktorska studentica Ekonomskog fakulteta Sveučilišta Matej Bel, Banská Bystrica, Slovačka, email: katarina.sulajova@gmail.com).

ORCID: https://orcid.org/0000-0002-1553-6276 
Data-intensive technologies, such as artificial intelligence, imply huge opportunities for transforming the delivery of healthcare and social services, improving people's quality of life and working in the health and welfare system. The aim of this paper is to present examples of the implementation of artificial intelligence techniques in healthcare and social services and to sketch the trends and challenges in the adoption of artificial intelligence techniques, with an emphasis on the public sector and selected public services. Analysis is based on a realistic assessment of current artificial intelligence technologies and their anticipated development. Besides the benefits and potential opportunities for healthcare and social services, there are also challenges for governments. Understanding the huge potential of artificial intelligence as well as its limitations will be a key step forward, but it is essential to avoid the trap of an overestimation of artificial intelligence potential. ${ }^{1}$

Keywords: artificial intelligence, public services, healthcare services, social services

\section{Introduction}

The widespread application of artificial intelligence (AI) in the private sector is also beginning to affect the public sector. Despite the development of artificial intelligence, research on its application in the public sector is very modest and sporadic. On the one hand, the implementation of $\mathrm{AI}$ is a tool for increasing the efficiency and effectiveness of public services, automating cognitive work, improving predictive decision-making skills, and improving services for citizens (Eggers, Schatsky \& Viechnicki, 2017). On the other hand, its implementation in the public sector and public services also presents some degree of uncertainty regarding the processing of per-

${ }^{1}$ We would like to thank the software developer Jakub Štefanišin from Siemens Healthineers Slovakia for helpful comments and suggestions on the draft of this article. The authors declare no conflict of interest. The funders had no role in the design of the study; in the collection, analyses, or interpretation of data; in the writing of the manuscript, or in the decision to publish the results. This contribution was funded by VEGA (grant number 1/0334/19). 
sonal data, digital tracking, and can also reduce the number of jobs due to automation (Janssen \& Kuk, 2016).

Artificial intelligence techniques are currently starting to be implemented significantly in the field of healthcare services, which is the key area of their adoption in the public sector (Sun \& Medaglia, 2019). The reason is that the area of healthcare services has a great potential for implementing AI to carry out various activities, such as analysing health records, assisting with repetitive tasks, designing treatment plans, etc. (e.g. Mesko, 2016). However, the current demographic trend - rapid population aging, one of the greatest challenges in many developed countries of the world, creates the potential for the implementation of AI techniques also in the field of social services (e.g. Broadbent, Stafford \& MacDonald, 2009; Simou, Alexiou \& Tiligadis, 2014; Torras, 2014; etc.).

The use of AI in the public sector in the future will be affected by limited public resources and the low level of citizens' trust in the public sector and the aforementioned technologies. This contribution analyses, discusses and presents the possibilities of using artificial intelligence in the public sector, namely in selected types of public services such as healthcare and social services, as well as the trends and potential challenges. The aim of this paper is to present examples of the implementation of artificial intelligence with an emphasis on the public sector and selected public services, based on a realistic assessment of the current artificial intelligence technologies and their anticipated development. The analysis of the paper is based on analysing more than 70 relevant papers, reports and other documents describing and analysing some examples of the implementation of AI techniques in healthcare and social services around the world. We used a comparative approach and case analysis to provide an overview of the topic under study. The mentioned studies containing examples of the implementation of AI techniques in healthcare and social services were selected on the basis of their relevance to the researched area of public services. In the area of healthcare services, we focused mainly on showing progress in the field of medical records, diagnostics, decision support for physicians, medical robots and reducing costs in hospitals. In the area of social services, we paid particular attention to showing progress in the field of social robotics for cooperation with disabled people and the elderly, to robots developed as support for teachers, and also to robots providing care in the field of social services. We have tried to provide a clear, concise and interesting overview of the current implementation of AI techniques in selected public services, and to stimulate a simple discussion on a specific issue to motivate further researchers. 


\section{Using Artificial Intelligence in Public Services}

Artificial intelligence is one of the newest areas of science and technology, although work on this area began after World War II. This field has been formally researched to a greater extent since the 1950s (Reddy, Fox \& Purohit, 2018). It is the science and technology of intelligent machine production, with a focus on intelligent computer programmes. It is related to the role of using computers to understand human intelligence, but artificial intelligence need not be limited to methods that are biologically observable (McCarthy, 2007). Artificial intelligence allows machines to learn from lessons learned, modify outputs and perform human tasks, which can be considered as a simulation of human intelligence and can include voice and visual recognition systems.

Figure 1: Various definitions of the "A" of "AI"

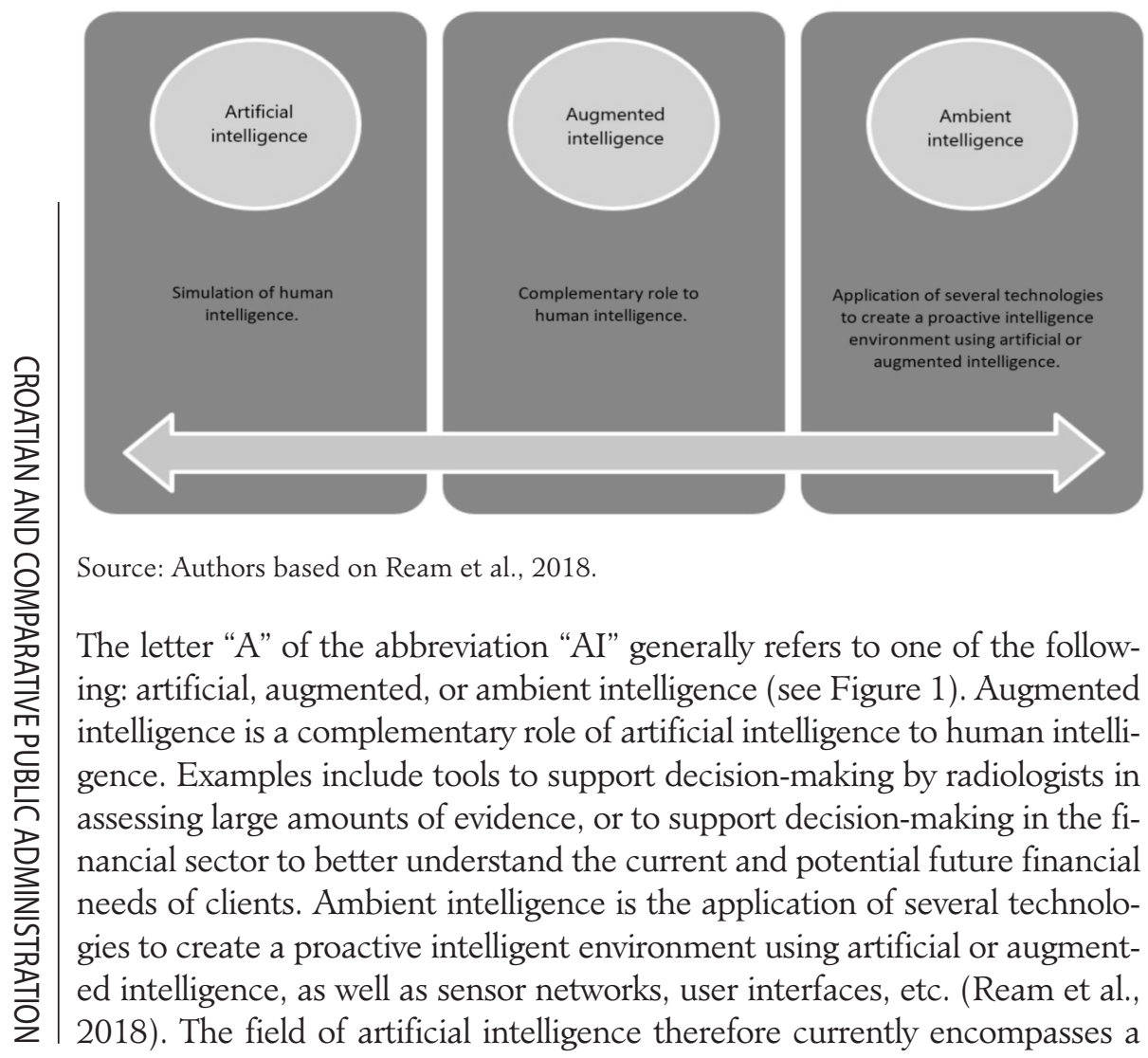


huge range of sub-areas, from general ones, such as learning and perception, to specific ones, such as driving a car, diagnosing diseases, predicting financial markets, and so on. Artificial intelligence thus represents a universal area for solving various intellectual tasks (Russell \& Norvig, 2016).

Even in the recent past, the potential of artificial intelligence could not be sufficiently exploited, mainly due to data constraints, computing capacity but also funding. However, the present, represented by increased interest in computing and the acute need to process huge amounts of data, together with increasing flows of funds into this area, brings a more optimistic perspective for the use of artificial intelligence (Reddy et al., 2018). The ability of AI to contribute to addressing some public sector problems in many countries, such as the increasing administrative burden due to large data processing, long waiting times and the associated delays in public service provision etc., forces governments to invest in artificial intelligence in these areas as well (Wirtz et al., 2018). AI techniques can improve work efficiency, automate certain processes, reduce administrative burdens, and improve the quality of services delivered. Governments around the world are beginning to recognise the potential of artificial intelligence for their country's economic and social progress (Eggers, Schatsky \& Viechnicki, 2017).

Implementation of AI in public services is already under way, albeit at different rates, in different countries and in different ways. Of course, not all risks and challenges related to the $\mathrm{AI}$ area are yet known, which may be one of the reasons for the slower implementation of artificial intelligence in the public sector (Anderson \& Agarwal, 2011; Boyd \& Crawford, 2012; Reddy et al., 2018; Pencheva, Esteve \& Mikhaylov, 2018; etc.). Today, artificial intelligence is triggering massive changes in the public sector and public services, precisely by transforming the way in which the public sector and public service employees perform their work. Some jobs will most likely disappear, some other jobs will also be redesigned and new jobs created for completely new professions. Although large job cuts are unlikely in the near future, cognitive technologies will change the nature of many jobs in the public sector and hence the provision of public services. The following subchapters are devoted to some examples of the implementation of artificial intelligence in selected public services in the world.

\section{Healthcare Services and Artificial Intelligence}

The potential of using artificial intelligence in healthcare services is already undeniable. Numerous studies have already documented the suc- 
cessful implementation of $\mathrm{AI}$ in different areas of healthcare, whether it is health administration (Amato et al., 2019; Anderson \& Agarwal, 2011; Diamond, Mostashari \& Shirky, 2009; Dimitrov, 2016; Impedovo \& Pirlo, 2019; Winter \& Davidson, 2019; etc.), diagnosis, prediction and decision support for physicians (Anakal \& Sandhya, 2017; Arsene, Dumitrache \& Mihu, 2015; Esteva et al., 2017; Lynn, 2019; Meena et al., 2019; Samuel, Omisore \& Ojokoh, 2013; Seo, 2019; etc.), or medical robotics and related efforts to reduce the cost of healthcare services (Ballantyne, 2002; Barbash \& Glied, 2010; Slakey \& Davidson, 2019; etc.).

The health sector is one of the areas characterised by generating a huge amount of information about patients, diagnoses, new findings from research and so on. For this reason, in recent decades there has been a massive shift in the measurement and processing of various health information that is currently obtainable (Mesko, 2017). With this increasing administrative burden and resource scarcity, the complexity of health management and the provision of healthcare services is increasing (Reddy et al., 2018). IT tools help to alleviate this burden on healthcare services, while the most interesting tools have been identified as artificial intelligence and data mining techniques (Reddy et al., 2018). These tools make it possible to improve the quality of healthcare services, in particular through the processing of patient input data and automated examination of laboratory data and imaging results. This reduces the pressure on administrative requirements for doctors, giving doctors more time to carry out patient care (Derrington, 2017). Machine learning tools (e.g. transfer learning, contextual analysis, knowledge injection or knowledge distillation) can then assist doctors in obtaining accurate and relevant patient information in conjunction with electronic patient health records. However, there are still some gaps, in particular concerning the availability of data and the integration of such machine learning models with the existing electronic health record systems. Machine learning tools can also serve as decision support to help reduce doctors' mistakes and increase the quality, speed and efficiency of healthcare services. Using patient data and medical practice, machine learning algorithms are used in different fields of medicine to predict and diagnose various diseases, such as lung diseases (Anthimopoulos et al., 2016; Gorynski et al., 2014; Yilmaz, Ari \& Kocabicak, 2016; etc.), or often in radiology (Mazurowski et al., 2018; Saba et al., 2019; Wang \& Summers, 2012; etc.) and many other specialised areas of medicine. A reduction in potential medical errors is possible through the use of artificial intelligence by integrating so-called deep learning into electronic health records to help identify gaps in treatment protocols (Hernandez et al., 2017). However, it 
is always necessary to combine the expertise and experience of physicians with the possibilities of AI techniques.

Healthcare services can also use AI techniques in the form of optimised machine learning algorithms to support hospital planning and prioritise patients, which contribute to reducing waiting time and delivering healthcare services more effectively (Huang, Jennings \& Fox, 1995). For instance, the problem with patients who do not attend appointments complicates planning systems in healthcare facilities and leads to underutilisation of healthcare facilities capacity (Daggy et al., 2010). Accurate prediction of so-called no-show or missed deadlines can contribute to developing strategies to mitigate these critical changes in healthcare facilities, e.g. special management for patients with a high probability of not attending medical appointments based on parameter estimates that can provide an overview of how past patient behaviour affects patient behaviour in the future (Harris, May \& Vargas, 2016). This in turn can contribute to clinical planning decisions to improve patient services. This combination of extensive analytical tools helps healthcare organisations collaborate efficiently with patients, streamline hospital staff timing, or enable remote patient monitoring (Lieberman \& Mason, 2002).

Table 1: Selected types of artificial intelligence techniques and their use in bealthcare services

\begin{tabular}{|l|l|l|}
\hline $\begin{array}{c}\text { Selected types } \\
\text { of artificial } \\
\text { intelligence } \\
\text { techniques }\end{array}$ & \multicolumn{1}{|c|}{ Method of use } & \multicolumn{1}{|c|}{ Examples } \\
\hline $\begin{array}{l}\text { Machine learning/ } \\
\text { Deep Learning }\end{array}$ & $\begin{array}{l}\text { Support planning in hospitals, } \\
\text { decision support for physi- } \\
\text { cians, patient monitoring, } \\
\text { identification of outbreaks of } \\
\text { various diseases, etc. }\end{array}$ & $\begin{array}{l}\text { Huang, Jennings \& Fox, 1995; } \\
\text { Chen et al., 2009; Daggy et al., } \\
\text { 2010; Harris, May \& Vargas, 2016; } \\
\text { Anakal \& Sandhya, 2017; Amato et } \\
\text { al., 2019; etc. }\end{array}$ \\
\hline Computer vision & $\begin{array}{l}\text { Radiology, surgery and other } \\
\text { specialised areas of medicine }\end{array}$ & $\begin{array}{l}\text { Jiang et al., 2005; Szeliski, 2011; } \\
\text { Mazurowski et al., 2018; Thevenot, } \\
\text { López \& Hadid, 2018; etc. }\end{array}$ \\
\hline Robots & $\begin{array}{l}\text { Surgery, ambulance, rehabili- } \\
\text { tation, etc. }\end{array}$ & $\begin{array}{l}\text { Ballantyne, 2002; Billard et al., } \\
\text { 2007; Barbash \& Glied, 2010; } \\
\text { Slakey \& Davidson, 2019; etc. }\end{array}$ \\
\hline Expert systems & $\begin{array}{l}\text { Prediction, treatment, knowl- } \\
\text { edge based and non-knowl- } \\
\text { edge based systems to support } \\
\text { clinical decision-making, etc. }\end{array}$ & $\begin{array}{l}\text { Arsene, Dumitrache \& Mihu, } \\
\text { 2015; Anthimopoulos et al., 2016; } \\
\text { Esteva et al., 2017; Lynn, 2019; } \\
\text { etc. }\end{array}$ \\
\hline
\end{tabular}

Source: Authors. 
Artificial intelligence is now a rapidly growing field with a wide range of applications (see Table 1). This area, fuelled by the economic constraints of countries and the potential to reduce human error, will be the engine of a vast array of diagnostic and treatment decisions traditionally made by doctors in the coming decades (Diprose \& Buist, 2016). While people will continue to be an important part of the provision of healthcare services, the scope for employing fewer health professionals in areas where AI tools have strengthened is undeniable.

\section{Social Services and Artificial Intelligence}

Given the growing need for social services (e.g. one of the greatest challenges in many developed countries of the world is rapid population aging), there is scope for the application of artificial intelligence techniques in this area as well (Torras, 2015). Rapid development of social robotics linked mainly to the development of robots for cooperation with the disabled (e.g. Taheri et al., 2019; etc.) and with older people (e.g. Rodic et al., 2016; etc.), or robots designed as support teachers (e.g. Cooney \& Leister, 2019; Han et al., 2008; Vitanza et al., 2019; etc.) or caregivers are beginning to reshape social services in many countries. The existing potential to provide social services in the form of human work and technology applications brings a completely new perspective on social services. Technologies used to administrate, manage and deliver social services can include assistive technologies such as mobile technologies or applications, or screen readers (Wynne et al., 2016), but also more sophisticated assisted living technologies such as telecare and telehealth, smart homes, or social robots (Dunn, Braddell \& Sunderland, 2014; Wigfield et al., 2013). One of the most significant challenges of the current demographic trends is the aging population, which requires new ways of addressing the quality of life of older people. Remarkable progress in areas such as mechanics, electronics and computer technology has led to the development of socalled humanoid robots, which are not used in factories, but are designed to interact with people in care provision and generally in the service sector (Torras, 2014). This technological advancement in assistive robotics brings various assistive skills to support long-term independent living, improve healthcare and reduce social isolation of older people (Koceska et al., 2019). These support technologies such as e-care systems, proactive service systems, interactive home robots, or tracking systems for the elder- 
ly are now being used in collaboration with nurses and family members to create better conditions for the life of older people through emotional and physical relief (Broadbent, Stafford \& MacDonald, 2009; Sasaki et al., 2007; Wada et al., 2003). Assistive robots for older people can be divided into rehabilitation robots and socially assistive robots (Broekens, Heerink \& Rosendal, 2009; Feil-Seifer \& Matarić, 2005). While rehabilitation robots provide physical assistance such as artificial limbs or intelligent wheelchairs, social assistance robots can be companion or service robots (Flandorfer, 2012; Torras, 2014). However, the field of social robotics no longer focuses only on the development of robots that meet the basic rules of care such as entertainment, safety and healthcare. Challenges in the form of geriatric medicine are at the forefront of focusing on the development of symptomatic recognition of frailty (Torras, 2014).

Robotics could thus contribute to promoting social services (see Table 2) and connecting users at home, i.e. at home and in hospital. Better care and support for an independent life is certainly cheaper and, more importantly, represents steps towards a more independent life for older people. Social robotics also includes the use of socially interactive robots to work with the disabled, and the use of socially interactive robots in collaboration with children with autism is becoming very popular (Boccanfuso \& O'Kane, 2011; Cabibihan et al., 2013; Duthenhahn, 2003; Billard et al., 2007; etc.). In particular, it is about helping the social, emotional and communication deficit. The development of socially interactive robots in the form of an imitator robot is often also used to teach children simple coordinated behaviour through their imitative abilities not only for children with autism but also for the rehabilitation of children with complex developmental disabilities (Billard et al., 2007). These robots also provide the possibility of interactive games for multiple children, involving their robot in a cooperative game of alternating imitations of different poses. These games are designed to increase attention, boost turnover skills, and promote verbal and non-verbal communication (Boccanfuso \& O'Kane, 2011). 
Table 2: Selected types of artificial intelligence techniques and their use in social services

\begin{tabular}{|l|l|l|}
\hline $\begin{array}{c}\text { Selected types } \\
\text { of artificial } \\
\text { intelligence } \\
\text { techniques }\end{array}$ & \multicolumn{1}{|c|}{ Method of use } & \multicolumn{1}{c|}{ Examples } \\
\hline $\begin{array}{l}\text { Method for detec- } \\
\text { tion/Sensors }\end{array}$ & $\begin{array}{l}\text { Smart home, assisted living } \\
\text { applications }\end{array}$ & $\begin{array}{l}\text { Chan et al., 2008; Chaaraoui, } \\
\text { Climent-Perez \& Florez-Revuelta, } \\
\text { 2012; Botia,Villa \& Palma, 2012; } \\
\text { Chernbumroong et al., 2013; etc. }\end{array}$ \\
\hline $\begin{array}{l}\text { Expert systems } \\
\text { Voice recognition } \\
\text { Screen readers }\end{array}$ & e-care, telecare, telehealth & $\begin{array}{l}\text { Antonicelli et al., 2008; Aanesen, } \\
\text { Lotherington \& Olsen, 2011; } \\
\text { Damant et al., 2013; Andres et al., } \\
\text { 2018; Akerlind, Martin \& Gustafs- } \\
\text { son, 2019; etc. }\end{array}$ \\
\hline Robots & $\begin{array}{l}\text { Care for elderly and disabled } \\
\text { people, support of inde- } \\
\text { pendent life of elderly and } \\
\text { disabled people, therapy, } \\
\text { rehabilitation, etc. }\end{array}$ & $\begin{array}{l}\text { Billard et al., 2007; Broadbent, } \\
\text { Stafford \& MacDonald, 2009; } \\
\text { Boccanfuso \& OKane, 2011; Flan- } \\
\text { dorfer, 2012; Wigfield et al., 2013; } \\
\text { Koceska et al., 2019; etc. }\end{array}$ \\
\hline
\end{tabular}

Source: Authors.

Robots and autonomous systems, together with artificial intelligence, interconnected data and digital infrastructure, can thus create the potential for a revolution in the way social and healthcare services are delivered.

\section{Discussion}

Huge advancements in AI research and processing (the so-called Big Data) enable widespread use of AI techniques and technologies in healthcare and social services (Ream et al., 2018). While research in this area is still to a greater degree at an early stage, current technologies implemented in practice are moving the future from models of reactive care to models of greater personalisation and proactivity. However, this raises challenges in the field of healthcare and social services (from technical and application risks to moral objections).

Healthcare services are a key area for the adoption of AI techniques and technologies in the public sector. The health sector is one of the sectors with the highest investment in new technologies (Yang et al., 2012), and where artificial intelligence has the greatest potential to carry out trans- 
formational work such as treatment records, job assistance and designing treatment plans and such like. In addition, the health sector is characterised by unique characteristics linked to the complexity of its stakeholder system, which includes not only the government shaping health policy, but also public hospitals as healthcare service providers and private companies that provide information technology. One problem, however, is the divergent views of these stakeholders on the challenges arising from the application of artificial intelligence techniques in this field. The potential of AI capabilities to automate and improve the delivery of healthcare services is unquestionable. AI techniques in the form of machine learning are already widely used to accelerate drug development and market entry (Saria, 2014), or to predict the outcome of critically ill patients (Ramesh et al., 2004). An equally huge breakthrough is in the field of epidemiology, where AI techniques are used for syndromic surveillance to identify outbreaks of various diseases (Chen et al., 2009). At the same time, computationally and technologically stronger programmes provide the ability to generate and test new hypotheses, allowing for the prediction of the spread of diseases and identifying patients most likely to be subject to disease; and providing accurate public health interventions with maximum effectiveness (Flahault et al., 2017). However, the implementation of robotics has indisputable potential in the field of healthcare services, as various types of robots, whether mobile autonomous robots, industrial robots or educational robots, are already used in the health sector. It is exactly the development of realistic looking so-called humanoid robots or virtual health assistants which is supporting the accelerated incorporation of artificial intelligence into the field of healthcare services (Reddy et al., 2018).

While the demand for the application of AI techniques and robotic solutions is growing, doubts exist concerning this so-called robotic revolution. Many experts note that the use of robots can complicate the problems of isolation, noting that people will need people to ensure their emotional and psychosocial well-being (Broadbent, Stafford \& MacDonald, 2009; Flandorfer, 2012; Damant et al., 2013; Koceska et al., 2019 etc.). However, the examples presented in this contribution point to the fact that the use of artificial intelligence techniques and robotic solutions can, to a certain extent, actually address care issues, whether medical or social, and the isolation of certain groups of people. Although the development in this area is still at the beginning, the possibilities of application of robots and autonomous systems in the provision of social services and social care are starting to gain real contours, not only in the coming decades, but al- 
ready today. They are likely to play an important role not only in the lives of older people and their active and dignified aging, but also in the lives of children whose parents are busy. What was once developed in the field of literary works, i.e. ethical questions with regard to the influence of robotic babysitters on the child's psyche, is now discussed in scientific forums (Torras, 2015). However, it should be pointed out that the method, scope and efficiency of the implementation of artificial intelligence techniques (i.e. in the form of social robots) is determined by the diversity of the welfare system and the different cultural values in the field of healthcare of individual countries.

Although there is a fairly wide range of literature on the promises of AI and robotics techniques in the field of healthcare and social services, an empirical examination of the potential challenges and possibly unintended consequences of these technologies in healthcare and social services is needed. It is precisely building security and confidence in their implementation that will be a crucial point for the adoption of these technologies in the lives and homes of citizens. However, this security must include mechanical security, software security and physical security.

Undoubtedly, with the rapid growth in the application of artificial intelligence techniques, considerable challenges are also coming to the fore. One of these challenges is the need to create new ethical and regulatory frameworks that need to be set to respond flexibly and keep pace not only with this rapid progress but also with the changing public sector and public services environment. However, this will require the involvement of a new generation of professionals specialising in high-risk environments such as healthcare services, as many current regulations do not respond to current technological progress (Cresswell, Cunningham-Burley \& Sheikh, 2018). Future developments will also require the creation of an open, transparent, clearly regulated and competitive market for emerging healthcare and social services technologies. The creation of such an environment should enable artificial intelligence and other innovations to be given the opportunities needed to achieve the best possible outcomes for those who receive, provide and manage healthcare and social services (Ream et al., 2018).

It is possible that in the future there will be health and social care systems using the latest knowledge and developments in mathematics, statistics, electrical engineering, neurophysiology, information technology, physics, but also epidemiology. This set of areas, which will work together within the health system, should ensure the most efficient and effective provision of healthcare and social services using data, artificial intelligence and 
innovation for the prevention, early diagnosis and treatment of diseases in order to improve the overall quality of life for citizens. However, the complexity and uniqueness of the public sector and public services in the form of the existence of multiple stakeholders, institutional complexity, including multilevel governance, together with scientific uncertainty, is a factor that significantly influences and will influence the process of applying AI to the public sector and public services. The specific nature of this issue thus includes not only cognitive-analytical and technical challenges, but also communication, political and institutional barriers.

\section{Conclusion}

New technologies that harness the power of data, such as artificial intelligence, create tremendous opportunities to transform healthcare and social services delivery, improve people's quality of life, and work within the health and social care system.

The progress of computing and data science in the areas of administration, mining, integration, classification, filtering and data visualisation, together with engineering innovations in the form of healthcare and social services tools, gave impetus to the creation of more complex, comprehensive but mainly non-standard solutions of the most pressing issues in health and social care. Artificial intelligence is changing the way healthcare and social services are delivered, yielding promising results in the form of integrated health information systems, epidemiological and syndromic surveillance, predictive modelling, decision support, medical imaging, mobile health, geriatric medicine, preventing the exclusion of older and disabled people, rehabilitation care, and so on. However, the way, scope and efficiency of the implementation of AI techniques (i.e. in the form of social robots) will be shaped by the diversity of the welfare system and the different cultural values in the field of healthcare of individual countries.

The recent rapid advances in the development of artificial intelligence, its accelerating pace, together with the resources provided by governments and industry, imply a widespread use of AI in the provision of healthcare and social services, as well as a vast potential for their development. The benefits of cost savings, improved visibility, reduced waiting times, increased speed, accuracy and efficiency of services and thus improved quality of service are tempting, but the question remains how, at what pace and to what extent these developments should and will take place. 
Understanding the huge potential of artificial intelligence as well as its limitations will be a key step forward. However, the trap of overestimating the potential of AI should be avoided. An important and necessary step will be to establish mechanisms to improve data quality and basic data infrastructure, together with ensuring a secure, proven and transparent approach to algorithm development and innovation in healthcare and social services. To the fore is the need to solve the so-called soft issues related to fair and open access to data, accountability for decision-making legal issues, data scalability and integration, security, privacy and ethics of aggregated digital data, and so on, and these are just some examples of future challenges. Just as the development of artificial intelligence brings enthusiasm for its benefits and potential opportunities for healthcare and social services, it also poses challenges for governments, and therefore these applications in the health and social care sector must be thoroughly and carefully planned.

Despite mentioned limitations, AI tools and techniques that are still under development already provide substantial benefits in the provision of healthcare services and social services, and their use for public services is likely to increase substantially in the near future. AI tools will be used extensively in these public services because of their huge potential for cost saving in future, but also public service quality improvement. Future development of the study will focus on the discussion of the computational complexity and cost of the main AI methods cited.

\section{References}

Aanesen, M., Lotherington, A. T., \& Olsen, F. (2011). Smarter elder care? A cost-effectiveness analysis of implementing technology in elder care. Health Informatics Journal, 17(3),161-172, https://doi.org/10.1177/1460458211409716

Akerlind, C., Martin, L., \& Gustafsson, C. (2019). Care managers' perceptions of eHomecare: A qualitative interview study. European Journal of Social Work, 22(4), 634-646, https://doi.org/10.1080/13691457.2017.1366893

Amato, F., Marrone, S., Moscato, V., Piantadosi, G., Picariello, A., \& Sansone, C. (2019). HOLMeS: eHealth in the big data and deep learning era. Information, 10(2), 34, https://doi.org/10.3390/info10020034

Anakal, S., \& Sandhya, P. (2017). Clinical decision support system for chronic obstructive pulmonary disease using machine learning techniques. Retrieved from https:// ieeexplore.iee.org/document/8284601, https://doi.org/10.1109/ICEECCOT.2017. 8284601 
Anderson, C. L., \& Agarwal, R. (2011). The digitization of healthcare: Boundary risks, emotion, and consumer willingness to disclose personal health information. Information Systems Research, 22(3), 469-490, https://doi.org/10.1287/ isre. 1100.0335

Andres, E., Zulfiqar, A. A., Talha, S., Hajjam, M., \& Hajjam, A. (2018). Telemedicine in elderly patients with heart failure. Geriatrie et Psychologie Neuropsychiatrie de Vieillissement, 16(4), 341-348, https://doi.org/10.1684/pnv.2018.0758

Anthimopoulos, M., Christodoulidis, S., Ebner, L., Christe, A., \& Mougiakakou, S. (2016). Lung pattern classification for interstitial lung diseases using a deep convolutional neural network. IEEE Transactions on Medical Imaging, 35(5), 1207-1216, https://doi.org/10.1109/TMI.2016.2535865

Antonicelli, R., Testarmata, P., Spazzafumo, L., Gagliardi, C., Bilo, G., Valentini, M., Olivieri, F., \& Parati, G. (2008). Impact of telemonitoring at home on the management of elderly patients with congestive heart failure. Journal of Telemedicine and Telecare, 14(6), 300-305, https://doi.org/10.1258/ jtt.2008.071213

Arsene, O., Dumitrache, L., \& Mihu, I. (2015). Expert system for medicine diagnosis using software agents. Expert Systems with Applications, 42(4), 18251834, https://doi.org/10.1016/j.eswa.2014.10.026

Ballantyne, G. H. (2002). Robotic surgery, telerobotic surgery, telepresence, and telementoring - Review of early clinical results. Surgical Endoscopy and Other Interventional Techniques, 16(10), 1389-1402, https://doi.org/10.1007/s00464001-8283-7

Barbash, G. I., \& Glied, S. A. (2010). New technology and health care costs The case of robot-assisted surgery. New England Journal of Medicine, 363(8), 701-704, https://doi.org/10.1056/NEJMp1006602

Boyd, D., \& Crawford, K. (2012). Critical questions for big data: Provocations for a cultural, technological, and scholarly phenomenon. Information, Communication \& Society, 15(5), 662-679, https://doi.org/10.1080/136911 8X.2012.678878

Broekens, J., Heerink, M., \& Rosendal, H. (2009). Assistive social robots in elderly care: A review. Gerontechnology, 8(2), 94-103, https://doi.org/10.4017/ gt.2009.08.02.002.00

Billard, A., Robins, B., Nadel, J., \& Dautenhahn, K. (2007). Building Robota, a mini-humanoid robot for the rehabilitation of children with autism. Assistive Technology, 19(1), 37-49, https://doi.org/10.1080/10400435.2007.10131864

Boccanfuso, L., \& O’Kane, J. M. (2011). CHARLIE: An adaptive robot design with hand and face tracking for use in autism therapy. International Journal of Social Robotics, 3(4), 337-347, https://doi.org/10.1007/s12369-011-0110-2

Botia, J. A., Villa, A., \& Palma, J. (2012). Ambient assisted living system for inhome monitoring of healthy independent elders. Expert Systems with Applications, 39(9), 8136-8148, https://doi.org/10.1016/j.eswa.2012.01.153

Broadbent, E., Stafford, R., \& MacDonald, B. (2009). Acceptance of healthcare robots for the older population: Review and future directions. International 
Journal of Social Robotics, 1(4), 319-330, https://doi.org/10.1007/s12369-0090030-6-

Cabibihan, J. J., Javed, H., Ang, M., \& Aljunied, S. M. (2013). Why robots? A survey on the roles and benefits of social robots in the therapy of children with autism. International Journal of Social Robotics, 5(4), 593-618, https://doi. org/10.1007/s12369-013-0202-2

Chaaraoui, A. A., Climent-Perez, P., \& Florez-Revuelta, F. (2012). A review on vision techniques applied to human behaviour analysis for ambient-assisted living. Expert Systems with Applications, 39(12), 10873-10888, https://doi. org/10.1016/j.eswa.2012.03.005

Chan, M., Esteve, D., Escriba, C., \& Campo, E. (2008). A review of smart homes - Present state and future challenges. Computer Methods and Programs in Biomedicine, 91(1), 55-81, https://doi.org/10.1016/j.cmpb.2008.02.001

Chen, H. CH., Zeng, D., Buckeridge, D. L., Tabaeh Izadi, M., Verma, A., Okhmatovskaia, A., Hu, X., Shen, X., Cao, Z., Wang, F., Xiaolong, Z., \& Wang, Q. (2009). AI for global disease surveillance. IEEE Intelligent Systems, 24(6),66-82, https://doi.org/10.1109/MIS.2009.126

Chernbumroong, S., Cang, S., Atkins, A., \& Yu, H. N. (2013). Elderly activities recognition and classification for applications in assisted living. Expert Systems with Applications, 40(5), 1662-1674, https://doi.org/10.1016/j. eswa.2012.09.004

Cooney, M., \& Leister, W. (2019). Using the engagement profile to design an engaging robotic teaching assistant for students. Robotics, 8(1), 21, https:// doi.org/10.3390/robotics8010021

Cresswell, K,, Cunningham-Burley, S., \& Sheikh, A. (2018). Health care robotics: Qualitative exploration of key challenges and future directions. Journal of Medical Internet Research, 20(7), https://doi.org/10.2196/10410

Daggy, J., Lawley, M., Willis, D., Thayer, D., Suelzer, C., DeLaurentis, P. C., Turkcan, A., Chakraborty, S., \& Sands, L. (2010). Using no-show modeling to improve clinic performance. Health Informatics Journal, 16(4), 246-259, https://doi.org/10.1177/1460458210380521

Damant, J., Knapp, M., Watters, S., Freddolino, P. P., Ellis, M., \& King, D. R. (2013). The impact of ICT services on perceptions of the quality of life of older people. Journal of Assistive Technologies, 7(1), 5-21, https://doi. org/10.1108/17549451311313183

Derrington, D. (2017). Artificial intelligence for health and health care. Retrieved from https://www.healthit.gov/sites/default/files/jsr-17-task-002_aiforhealthandhealthcare12122017.pdf

Diamond, C. C., Mostashari, F., \& Shirky, C. (2009). Collecting and sharing data for population health: A new paradigm. Health Affairs, 28(2), 454-466, https://doi.org/10.1377/hlthaff.28.2.454

Dimitrov, D. V. (2016). Medical internet of things and Big Data in healthcare. Healthcare Informatics Research, 22(3), 156-163, https://doi.org/10.4258/ hir.2016.22.3.156 
Diprose, W., \& Buist, N. (2016). Artificial intelligence in medicine: Humans need not apply? New Zeland Medical Journal, 129(1434),73-76.

Dunn, S., Braddell, A., \& Sunderland, J. (2014). Digital capabilities in social care. Final report for skills for care. Leeds: Skills for Care. Retrieved from https:// www.skillsforcare.org.uk/Document-library/NMDS-SC,-workforce-intelligence-and-innovation/Research/Digital-literacy/Digital-Capability-Rapid-Evidence-Review-300714-FINAL.pdf

Eggers, W. D., Schatsky, D., \& Viechnicki, P. (2017). AI-augmented government. Using cognitive technologies to redesign public sector work. Retrieved from<https://www2.deloitte.com/insights/us/en/focus/cognitive-technologies/ artificial-intelligence-government.html

Esteva, A., Kuprel, B., Novoa, R., Ko, J., Swetter, S. M., Blau, H. M., \& Thrun, S. (2017). Dermatologist-level classification of skin cancer with deep neural networks. Nature, 542(7639),115-118, https://doi.org/10.1038/nature21056

Feil-Seifer, D., \& Matarić, M. J. (2005). Defining socially assistive robotics. Retrieved from https://ieeexplore.ieee.org/document/1501143

Flandorfer, P. (2012). Population ageing and socially assistive robots for elderly persons: The importance of sociodemographic factors for user acceptance. International Journal of Population Research, 2012, 2090-4029, https://doi. org/10.1155/2012/829835

Flahault, A., Geissbuhler, A., Guessous, I., Guérin, P., Bolon, I., Salathé, M., \& Escher, G. (2017). Precision global health in the digital age. Swiss Medical Weekly,1314,14423, https://doi.org/10.4414/smw.2017.14423

Goryński, K., Safian, I., Grądzki, W., Marszall, M. P., Krysiński, J., Goryński, S., Bitner, A., Romaszko, J., \& Buciński, A. (2014). Artificial neural networks approach to early lung cancer detection. Central European Journal of Medicine, 9(5), 632-641, https://doi.org/10.2478/s11536-013-0327-6

Han, J., Jo, M., Jones, V., \& Jo, J. H. (2008). Comparative study on the educational use of home robots for children. Journal of Information Processing Systems, 4(4), 159-168, https://doi.org/10.3745/JIPS.2008.4.4.159

Harris, S. L., May, J. H., \& Vargas, L. G. (2016). Predictive analytics model for healthcare planning and scheduling. European Journal of Operational Research, 253(1), 121-131, https://doi.org/10.1016/j.ejor.2016.02.017Urena, A., Salcedo, I., Espinosa-Anke, L., \& Saggion, H. (2017). Savana: Re-using electronic health records with artificial intelligence. International Journal of Interactive Multimedia and Artificial Intelligence, 1, 8-12, https://doi.org/10.9781/ ijimai.2017.03.001

Huang, J., Jennings, N. R., \& Fox, J. (1995). An agent-based approach to health care management. Applied Artificial Intelligence: An International Journal, 9(4),401-420, https://doi.org/10.1080/08839519508945482

Impedovo, D., \& Pirlo, G. (2019). eHealth and artificial intelligence. Information, 10(3), 117, https://doi.org/10.3390/info10030117 
Janssen, M., \& Kuk, G. (2016). The challenges and limits of big data algorithms in technocratic governance. Government Information Quarterly, 33(3), 371-377, https://doi.org/10.1016/j.giq.2016.08.011

Jiang, L. J., Ng, E. Y., Yeo, A. C., Wu, S., Pan, F., Yau, W. Y., Chen, J. H., \& Yang, Y. (2005). A perspective on medical infrared imaging. Journal of Medical Engineering and Technology, 29(6), 257-267, https://doi.org/10.1080/0309 1900512331333158

Koceska, N., Koceski, S., Zobel, P. B., Trajkovik, V., \& Garcia, N. (2019). A telemedicine robot system for assisted and independent living. Sensors, 19(4), 834, https://doi.org/10.3390/s19040834

Lieberman, H., \& Mason, C. (2002). Intelligent agent software for medicine. Studies in bealth technology and informatics, 80, 99-109.

Lynn, L. A. (2019). Artificial intelligence systems for complex decision-making in acute care medicine: A review. Patient Safety In Surgery, 13(1), https://doi. org/10.1186/s13037-019-0188-2

Mazurowski, M. A., Buda, M., Saha, A., \& Bashir, M. R. (2018). Deep learning in radiology: An overview of the concepts and a survey of the state of the art with focus on MRI. Journal of Magnetic Resonance Imaging, 49(4), 939-954, https://doi.org/10.1002/jmri.26534

Meena, K., Tayal, D. K., Gupta, V., \& Fatima, A. (2019). Using classification techniques for statistical analysis of anemia. Artificial Intelligence In Medicine, 94, 138-152, https://doi.org/10.1016/j.artmed.2019.02.005

Mesko, B. (2016). Artificial Intelligence will redesign healthcare. Retrieved from https://medicalfuturist.com/artificial-intelligence-will-redesign-healthcare

Mesko, B. (2017). The role of artificial intelligence in precision medicine. Expert Review of Precision Medicine and Drug Development, 2, 239-241, https://doi.org /10.1080/23808993.2017.1380516

Pencheva, I., Esteve, M., \& Mikhaylov, S. J. (2018). Big data and AI - A transformational shift for government: So, what next for research? Public Policy and Administration, 35(2), 24-44, https://doi.org/10.1177/0952076718780537

Ramesh, A. N., Kambhampati, C., Monson, J. R. T., \& Drew, P. J. (2004). Artificial intelligence in medicine. Annals of The Royal College of Surgeons of England, 86, 334-338, https://doi.org/10.1308/147870804290

Ream, M., Woods, T., Joshi, I., \& Da, L. (2018). Accelerating artificial intelligence in health and care: Results from a state of the nation survey. Retrieved from https://wessexahsn.org.uk/img/news/AHSN\%20Network\%20AI\%20Report-1536078823.pdf

Rodic, A., Vujovic, M., Stevanovic, I., \& Jovanovic, M. (2016). Development of human-centered social robot with embedded personality for elderly care. In P. Wenger, C. Chevallereau \& D. Pisla (Eds.), New trends in medical and service robots (pp. 233-247). Cham, Germany: Springer, https://doi. org/10.1007/978-3-319-30674-2_18

Russell, S. \& Norvig, P. (2016). Artificial Intelligence: A Modern Approach. Harlow, UK: Pearson Education Limited. 
Saba, L., Biswas, M., Kuppili, V., Cuadrado Godia, E., Suri, H. S., Reddy Edla, D., Omerzu, T., Laird, J. R., Khanna, N. N., Mavrogeni, S., Progogerou, A., Sfikakis, P. P., Viswanathan, V., Kitas, G. D., Nicolaides, A., Gupta, A., \& Suri, J. S. (2019). The present and future of deep learning in radiology. European Journal of Radiology,114, 14-24, https://doi.org/10.1016/j.ejrad.2019.02.038

Samuel, O. W., Omisore, M. O., \& Ojokoh, B. A. (2013). A web based decision support system driven by fuzzy logic for the diagnosis of typhoid fever. Expert Systems with Applications, 40(10), 4164-4171, https://doi.org/10.1016/j. eswa.2013.01.030

Saria, S. (2014). A $\$ 3$ trillion challenge to computational scientists: Transforming healthcare delivery. IEEE Intelligence Systems, 29, 82-87, https://doi. org/10.1109/MIS.2014.58

Sasaki, J., Yamada, K., Tanaka, M., \& Funyu, Y. (2007). An experiment of the life support network for elderly people living in a rural area. Retrieved from https:// citeseerx.ist.psu.edu/viewdoc/download?doi=10.1.1.613.4131\&rep=rep1\&type $=$ pdf

Seo, J. B. (2019). The role of medical doctor in the era of artificial intelligence. Journal of the Korean Medical Association, 62(3), 136-139, https://doi.org/10.5124/ jkma.2019.62.3.136

Simou, P., Alexiou, A., \& Tiligadis, K. (2014). Artificial humanoid for the elderly people. In P. Vlamos \& A. Alexiou (Eds.), GeNeDis 2014 (pp. 19-27). Cham, Germany: Springer, https://doi.org/10.1007/978-3-319-08939-3_7

Slakey, D. P., \& Davidson, I. (2019). Robotic surgery: An example of uncoupling the economics of technology. Health and Technology, 9(1), 25-29, https://doi. org/10.1007/s12553-018-0249-Z

Sun, T. Q., \& Medaglia, R. (2019). Mapping the challenges of artificial intelligence in the public sector: Evidence from public healthcare. Government Information Quarterly, 36(2), https://doi.org/10.1016/j.giq.2018.09.008

Szeliski, R. (2011). Computer vision: Algorithms and applications. London, UK: Springer-Verlag, https://doi.org/10.1007/978-1-84882-935-0

Taheri, A., Meghdari, A., Alemi, M., \& Pouretemad, H. R. (2019). Teaching music to children with autism: A social robotics challenge. Scientia Iranica, 26(1), $40-58$

Thevenot, J., López, M. B., \& Hadid, A. (2018). A survey on computer vision for assistive medical diagnosis from faces. IEEE Journal of Biomedical and Health Informatics, 22(5), 1479-1511, https://doi.org/10.1109/JBHI.2017.2754861

Torras, C. (2015). Social robots: A meeting point between science and fiction. Mêtode Science Studies Journal,5, 111-115, https://doi.org/10.7203/ metode.0.3546

Vitanza, A., Rossetti, P., Mondada, F., \& Trianni, V. (2019). Robot swarms as an educational tool: The Thymio's way. International Journal of Advanced Robotic Systems, 16(1), https://doi.org/10.1177/1729881418825186

Wada, K., Shibata, T., Saito, T., \& Tanie, K. (2003). Effects of robot assisted activity to elderly people who stay at a health service facility for the aged. 
Retrieved from http://cstwiki.wtb.tue.nl/images/Effects_of_Robot-Assisted_Activity_for_Elderly_People_and_Nurses_at_a_Day_Service_Center.pdf, https://doi.org/10.1109/JPROC.2004.835378

Wang, S., \& Summers, R. M. (2012). Machine learning and radiology. Medical Image Analysis, 16(5), 933-951, https://doi.org/10.1016/j.media.2012.02.005

Wigfield, A., Wright, K., Burtney, E., \& Buddery, D. (2013). Assisted living technology in social care: workforce development implications. Journal of Assistive Technologies, 7(4), 204-218, https://doi.org/10.1108/JAT-01-2013-0001

Winter, J. S., \& Davidson, E. (2019). Big data governance of personal health information and challenges to contextual integrity. Information Society, 35(1), 36-51, https://doi.org/10.1080/01972243.2018.1542648

Wirtz, J., Patterson, P. G., Kunz, W. H., Gruber, T., Nhat Lu, V., Paluch, S., \& Martins, A. (2018). Brave new world: Service robots in the frontline. Journal of Service Management, 29(5), 907-931, https://doi.org/10.1108/JOSM-042018-0119

Wynne, R., McAnaney, D., MacKeogh, T., Stapleton, P., Delaney, S., Dowling, N., \& Jeffares, I. (2016). Assistive technology/equipment in supporting the education of children with special educational needs - what works best? Retrieved from http://ncse.ie/wp-content/uploads/2016/07/NCSE-Assistive-Technology-Research-Report-No22.pdf

Yang, Z., Ng, B. Y., Kankanhalli, A., \& Luen Yip, J. W. (2012). Workarounds in the use of IS in healthcare: A case study of an electronic medication administration system. International Journal of Human Computer Studies, 70(1),43-65, https://doi.org/10.1016/j.ijhcs.2011.08.002

Yilmaz, A., Ari, S., \& Kocabicak, U. (2016). Risk analysis of lung cancer and effects of stress level on cancer risk through neuro-fuzzy model. Computer Methods and Programs in Biomedicine, 137, 35-46, https://doi.org/10.1016/j. cmpb.2016.09.002 


\section{IMPLEMENTATION AND APPLICATION OF ARTIFICIAL INTELLIGENCE IN SELECTED PUBLIC SERVICES}

\section{Summary}

The aim of this paper is to present examples of the implementation of artificial intelligence techniques in bealthcare and social services and to briefly sketch the trends and challenges in the adoption of artificial intelligence techniques, with an emphasis on the public sector and selected public services, based on a realistic assessment of current artificial intelligence technologies and their anticipated development. Data-intensive technologies, such as artificial intelligence, imply buge opportunities for transforming the delivery of healthcare and social services, improving people's quality of life, and working in the bealth and welfare system. With the benefits and potential opportunities for healthcare and social services, there are also challenges for governments, so these applications need to be thoroughly and carefully planned in these areas. Understanding the buge potential of artificial intelligence as well as its limitations will be a key step forward, but it is essential to avoid the trap of overestimating the potential of artificial intelligence. There is a need to solve the so-called soft issues related to fair and open access to data, responsibility for legal issues, security, privacy, ethics, etc. Some interesting examples of the implementation of artificial intelligence techniques in bealthcare and social services around the world were analysed, discussed and presented. Public sector practitioners need to be increasingly aware of the need for cooperation and exchange of information with artificial intelligence experts. It will not be possible without them in the future. Published studies or publicly available experience focused on selected public services. That is why a more indepth literature review focused on the healthcare and social services.

Keywords: artificial intelligence, public services, bealthcare services, social services 


\section{IMPLEMENTACIJA I PRIMJENA UMJETNE INTELIGENCIJE U ODABRANIM JAVNIM SLUŽBAMA}

\section{Sažetak}

Cilj je ovog članka predstaviti primjere implementacije tebnika umjetne inteligencije u sektorima zdravstvenib i socijalnib usluga i ukratko skicirati trendove $i$ izazove u pribvaćanju takvih tehnika. U radu je naglasak na javnom sektoru $i$ odabranim javnim službama, a temelji se na realističnoj ocjeni trenutačne tebnologije umjetne inteligencije i njezinu anticipiranom razvoju. Podatkorno intenzivne tebnologije kao što je umjetna inteligencija otvaraju velike prigode za transformaciju isporuke zdravstvenib $i$ socijalnib usluga, unaprjeđujući kvalitetu života ljudi $i$ rad u sektorima zdravstva $i$ socijalne skrbi. Osim mogućnosti $i$ potencijalnib koristi za navedene sektore javnih službi, korištenje umjetnom inteligencijom sa sobom nosi $i$ izazove za javne vlasti tako da implementacija umjetne inteligencije treba biti pomno planirana. Razumijevanje velika potencijala umjetne inteligencije, ali i njezinih ograničenja bit će korak naprijed jer je ključno izbjeći zamku njezina precjenjivanja. U tom je kontekstu potrebno riješiti tzv. meke probleme koji se odnose na otvoren pristup podacima, pravnu odgovornost, sigurnost, privatnost itd. U radu se analiziraju neki zanimljivi primjeri implementacije umjetne inteligencije $u$ dvama sektorima $i$ raspravlja o njima. Zaposlenici u javnom sektoru trebaju sve više biti svjesni potrebe za suradnjom i razmjenom informacija i iskustava sa stručnjacima za umjetnu inteligenciju jer bez njib u budućnosti neće biti moguće pružati usluge na zadovoljavajući način. Dostupna literatura i objavljene studije fokusiraju se uglavnom na odabrane javne službe pa je dubinski pregled literature obubvatio upravo njih.

Ključne riječi: umjetna inteligencija, javne službe, zdravstvene usluge, socijalne usluge 